\title{
Some paradoxes of prosodic research and what these may suggest about speech as multimodal communication
}

\section{Horst Arndt}

\section{Richard W. Janney}

A comparison of conflicting standpoints in prosodic research during the past few decade shows that linguists continue to disagree about how prosody should be approached as a subject of study and about where prosodic analysis ought to fit into linguistic theory and language teaching. Several basic issues remain unresolved: e.g., is prosody an observational or introspective fact of speech, is it cognitively or emotionally motivated, is it a sub-system of language or an independent vocal system in its own right? Paradoxes of prosodic research in these and other areas suggest that discovering what and how prosodic activities communicate may be a necessary prerequisite for further investigating relations between verbal, vocal, and kinesic signals in speech.

'n Vergelyking van teenstrydige standpunte in prosodiese navorsing die afgelope paar dekades toon aan dat taalkundiges nog steeds verskil oor hoe prosodie as vakgebied benader behoort te word en oor waar prosodiese ontleding in linguistiese teorie en taalonderrig behoort te pas. Verskeie grondliggende geskilpunte bly onopgelos, byvoorbeeld of prosodie ' $n$ waarnemings- of introspektiewe kenmerk van spraak is, of dit kognitief of emosioneel gemotiveer is, of dit ' $n$ sub-stelsel van taal of ' $n$ onafhanklike vokale stelsel op sigself (in sy eie reg) is? Geidentifiseerde paradokse wat spruit uit prosodiese navorsing op hierdie en ander terreine dui daarop dat dit noodsaaklik mag wees om te bepaal wat deur prosodiese aktiwiteite gekommunikeer word en hoe dit geskied. Dit sal 'n voorvereiste vir verdere 
ondersoek na die verhouding tussen verbale, vokale en liggaamseine in spraak wees.

\section{INTRODUCTION}

In the early seventies Chomsky's and Halle's (1968) integration of prosodic analysis into the transformational-generative framework as a subordinate aspect of linguistic analysis aroused strong disagreement among some nonsegmental phonologists and gave new life to old arguments about the nature of prosody (Gumperz, $1982: 107$ ). Subsequently, scholars began to question central assumptions behind Chomsky's and Halle's The Sound Patterns of English, and interest grew in studying nongrammatical functions of prosody, and there was mounting pressure for a reconsideration of the status of prosody in linguistic theory generally (Jakobson and Waugh, $1979: 235$ ). As a result, throughout the seventies and early eighties prosody became an increasingly controversial area of study (Vennemann, $1986: 15$ ).

The purpose of the present paper is to discuss some conflicting standpoints that emerged during this time, and to suggest some of their possible implications for future research on interrelated verbal, vocal, and kinesic aspects of speech. The paper is not intended to resolve the issues, or to defend sides in the questions discussed, which probably will not be answered definitively for some time. Rather, here we view the issues, and the stances of various groups of linguists with respect to these, as impetus for integrative reflections on speech as multimodal communication (Arndt and Janney, 1987b).

As we have discussed elsewhere at length, speaking a language fluently requires a mastery not only of its lexis and grammar, but also of its prosody and kinesics (Arndt and Stewart, 1982, 1983; Arndt and Pesch, 1983, 1984; Arndt, Janney and Pesch, 1984; Arndt and Janney, 1985a, 1985b). The importance of nonverbal aspects of speech - which in themselves are no less systematic, communicative, and culturally learned than the verbal aspects - has not been officially recognized by many linguists for various good theoretical and methodological reasons until relatively recently. Now, as the focus of linguistics shifts toward verbal communication, the value of broadening the study (and teaching) of speech beyond sentence grammar to include pragmatically relevant nonverbal vocal and kinesic activities is becoming increasingly apparent (Kendon, 1981; Key, 1982; Poyatos, 1983b).

The literature on English prosody shows that linguists, on the whole, have not always agreed about how prosody should be approached as an object of study, or about where prosodic analysis fits, or ought to fit, into linguistic theory (Raith, 1984). Lacking shared assumptions about basic issues, various groups of linguists have done interesting research on different aspects of prosody, but largely independently of each other. One problem seems to be that, 
having rejected transformational-generative phonological analysis, many investigators are still searching for an appropriate theoretical framework to fill the vacuum (Vennemann, $1986: 6$ ).

The term "prosody" is used in so many different contexts that explaining these in detail would require another paper (Klein, 1980:4). Here we will simply use it to refer to variations in loudness, pitch, and duration (including pauses) in speech (Crystal, 1979:33) that continue over longer utterance stretches - minimally a syllable (as with stress) - or require reference to several segments in different parts of an utterance (as with pitch contours). Vocal activities that cannot be related directly to linguistic features of speech, such as tone of voice, tempo, and pitch register, we will group loosely under the term paralanguage (Trager, 1958), warning the reader that this is only a conceptual distinction, not necessarily an observational or experiential fact of speech.

The vague status of prosody in linguistics has been a recurring theme in the literature for years, Prosody has been characterized variously as "the greasy part of language" (Bolinger, 1975), "the Golden Triangle of linguistics ... at the spot where syntax, phonology, and semantics uneasily come together" (Goldsmith, 1982), and "the interface between grammar and the real world" (Hirst, 1983). Couper-Kuhlen (1986: 173) writes:

The conclusion which many linguists have drawn is that intonation is 'on the edge of language', ... or worse yet, that (it) is wholly outside the realm of linguistics proper and is external to that central object of linguistic endeavor, the 'grammar'.

Indeed, the facts of prosody often seem to fit rather uncomfortably into the conceptual frameworks that we invent to account for the facts of language. Prosody seems to be neither fully dependent on, nor fully independent of, language. It appears to straddle the borders between that which we regard as symbolic and gestural in communication, cognitive and emotional in psychology, and verbal (of the mind) and kinesic (of the body) in speech. For these reasons, paradoxes of prosodic research are interesting to linguists who study speech as multimodal communication.

In the following pages we will address three issues which we feel may be important someday in further exploring the complex relationships between prosodic and other speech activities. In section 2 we focus on the problem of defining prosody as an object of study, discussing whether prosodic categories are observational or introspective facts of speech, and reviewing various notions about the perception, representation and analysis of prosodic phenomena. In section 3 we focus on prosody in relation to mental processes, discussing whether prosody is essentially a cognitive or emotive aspect of speech. In section 4 we focus on prosody in relation to language, paralanguage, and kinesics, 
discussing the issue of whether prosody is languagebound or an autonomous mode of communication. And in section 5 we suggest some of the implications of issues discussed in the preceding sections for future multimodal speech research.

\section{PROSODY AS AN OBJECT OF STUDY}

"A mass of noise, or rather of observations of noise, is thus reduced to a relatively simple set of contrastive exponents."

M.A.K. Halliday (1967 : 12)

The human voice is capable of producing a wide range of acoustic effects: tones, pitch contours, clicks, stops, stresses, levels of loudness, and so on. Prosodic effects result from different types of glottal excitation and temporal changes in the shape of the vocal tract, and are subject to different types of interference. There seems to be no nomenclature that is capable of adequately representing what Sapir (1927: 895) calls "the bewildering range of voice phenomena", and no electronic device capable of analyzing these phenomena quite like the human ear (Krause, 1984).

Precisely the acoustic complexity of the voice, and the difficulty of fully describing and analyzing speech sounds, raises the issue of the status of prosody as an object of study. Is prosody an observational fact of speech, a physically measurable parameter of human vocal activity that can be mechanically isolated and empirically investigated? Or is it an introspective fact that is called into existence by a decision to approach speech from a particular point of view (Saussure, 1916:23)? These are two standpoints in current prosodic research, and each has its supporters, although we cannot always distinguish between proponents of the two standpoints quite as easily as might be expected on the basis of what they write about the facts of prosody (Arndt and Janney, 1981; 1987b : 39 ff.).

\subsection{Prosodic facts}

Regardless of their theoretical and methodological alignments, investigators of prosody all face the difficulty of reducing what Halliday (1967:12) calls, "masses of noise" - actually, inferences about masses of noise that they designate as relevant facts - into simplified conceptual models before they can begin to do any type of systematic analysis (Anndt, 1981; Janney, 1981). Two features of this activity are important: first, the processes by which investigators decide which prosodic facts are to be analyzed; and second, the processes by which they reduce these designated facts to model objects of analysis (Arndt and Janney, 1987b: $13 \mathrm{ff}$.). 
Decisions as to which prosodic phenomena will be regarded as "factual" and "relevant" are always made by individuals who, by virtue of their training, linguistic group affiliation, and previous research experience, are perceptually and conceptually predisposed to approach this task in a particular way. This is true regardless of whether their basic approach is introspective or observational. Thus we may say that prosodic facts, like linguistic ones, tend to be determined to a certain degree in advance by investigators' interests and expectations, and by what Malinowski $(1920: 73)$ refers to as their "scientific mental habits". For this reason it is perhaps not surprising that scholars operating out of different research traditions often perceive radically different types of prosodic facts, and assign different relevance to these, making it sometimes difficult to compare their approaches and correlate their results.

Because basic conceptual distinctions between prosodic categories are often determined by a more or less arbitrary cutting of the continuum, as Halliday (1967: 30) puts it, there is generally a certain amount of disagreement between proponents of different approaches. Thus, for example, proponents of acoustic analysis complain that "impressions of 'nuclear prominence' are not ... elementary prosodic judgments" (Gibbon, $1984: 186$ ), while their critics claim that methods of pitch extraction "each introduce their own specific types of errors" (Krause, $1984: 250$ ). Proponents of linguistic analysis argue that intonation is a feature of grammar (Halliday, $1967: 10$ ), while supporters of other views claim that it is a feature of rhetoric (Knowles, $1984: 277$ ) or of semantics (Klein, 1982:289), or argue that it is not even a linguistic phenomenon in the narrow sense (Bolinger, 1982:259). In the face of ongoing disagreements about these and other fundamental issues, some linguists express disappointment with prosodic research generally (Crystal, 1975: 85):

On the whole, most field-workers, even in linguistics, are still unaware, in principle, of the kind of ... phenomenon they are liable to come into contact with in this (nonsegmental) part of language, how they should label the phenomena that they hear, or how they should integrate these with other aspects of any linguistic description they may happen to be making.

Given this situation, it seems that prosodic facts, whether introspective or observational, are best regarded as having "more/less" validity, and "more/less" relevance, depending on the types of questions they are intended to answer (Halliday, $1967: 9$ ). There will always be certain features of prosody (and other communicative phenomena) that lie outside the methods that we invent to analyze them and do not fit into the systems that we invent to account for them. 


\subsection{From prosodic facts to prosodic representations}

Before designated prosodic facts can be analyzed, they must be described, modelled, or represented in some fashion that enables the investigator to deal with them in a systematic manner (Arndt and Janney, 1987b : $13 \mathrm{ff}$.). We do not normally analyze individual prosodic events but rather concepts about types of prosodic events. The need to proceed systematically compels us to reduce our introspective or observational prosodic experiences to relatively simple schemata. We focus on what Wittgenstein (1953) calls "family resemblances" among these experiences, eliminating most of the individual differences, until we arrive at a sort of hypothetical sketch of the similarities between them. By this means, our unorganized perceptions of prosodic events are reduced to relatively discrete model objects of analysis (Bunge, $1973: 92$ ).

Because the formal features of model objects largely determine the types of analyses that we can perform on them, the issue of representation remains central to prosodic analysis at all times (Hirst, 1983: 94). Raith's (1984) review of contemporary prosodic notational systems shows that, generally speaking, these are restricted to indicating relatively simple contrasts of loudness and pitch along sequences of words in utterances. The simplicity of these systems - at least compared with the complexity of the phenomena that they represent - appears to hinder sophisticated prosodic analysis. A great deal of important vocal information seems to be currently unrepresentable, and thus unanalyzable. For this reason, it may well be true, as Hirst (1983:109) says, that "an adequate model for phonological representation might be a necessary prerequisite for a solution to the ... problem of how (prosody) contributes to the meaning of an utterance."

\subsection{Prosodic perceptions}

From a perceptual point of view it is not exactly evident where our prosodic categories, whether introspective or observational, actually come from. Although it may not be entirely accurate to claim, as Knowles (1984:242) does, that "tones are not a discovery but an invention", the acoustic evidence does cast doubt on various linguistic assumptions about prosodic features, suggesting that many of our prosodic distinctions - our "cutting of the continuum" are more analytical conveniences than physically measurable acoustic events (Raith, $1984: 522$ ).

On the other hand, acoustic research also reveals types of vocal variation that are indeed associated with prosody. Variations in pitch determined by fundamental frequency (Fo), and measured in herz (cycles per second), have long been studied in acoustic research (Hirst, $1983: 94$ ). The problem is only that the acoustic findings are sometimes difficult to reconcile with our linguistic 
notions about different features of prosody. Klein (1982), for example, claims that differences between stressed and unstressed syllables do not have concrete acoustic counterparts in spoken utterances, and claims that there is little evidence that sentence accents are related to measurable acoustic contours. Krause (1984: 243) says that human perceptions of pitch are not always clearly tied to physically measurable oscillations of acoustic signals. There are many examples of these types of statements in the psychoacoustic literature.

Hirst (1983 : 95), who has done some very interesting research on pitch extraction in recent years, says that "the fundamental frequency is not a continuously observable parameter of the sound wave, its presence or absence being dependent on the segmental feature of voicing". Differences in voicing, he explains, can distort the picture of pitch variation derived from acoustic measurement to the extent that utterances which would normally be expected to have the same phonetic representation, and thus presumably also the same phonological representation as far as their intonation is concerned, e.g.,

C'est papa? /sepapa/ (Is it daddy?)

C'est maman? /semama/ (Is it mommy?)

can have very different acoustic representations (see Figure 1).

How or why we perceive such utterances as having similar intonations, despite their apparently dissimilar acoustic profiles, is not exactly understood; but it seems to have something to do with the fact that people simply perceive and analyze acoustic events differently than acoustic analyzers do (Krause, 1984); and this, in turn, suggests an interesting hypothesis for reconciling some of the conflicting findings of observational and introspective prosodic research. Whereas acoustic analyzers operate in a linear fashion, measuring the spectral structures of acoustic events at constant intervals $(20-50 \mathrm{~m} \mathrm{sec})$ through time, the human ear appears to operate in a nonlinear, time variable fashion, focusing attention selectively on particular aspects of the sound stream (and ignoring others) at different, often much shorter intervals (4-10 m sec) (Krause, 1984 : 244). As a result, the human ear is able to recognize very small pitch variations as individual voice characteristics, and is able to perceive complex relationships between these through time. The ability to recognize temporal relationships between acoustic events may be what enables people to "fill in the empty spaces", as it were, and hear (or project) smoothly rising or falling intonations where none can be measured acoustically.

Does the ear then invent prosodic contrasts? Probably not exactly. We know that prosody - intonation in particular - is one of the most deep-rooted characteristics of individual languages (Hirst and di Cristo, 1984 : 555). The prosodic structure of a language seems to be what a native speaker learns first (de Boysson-Bardies, 1982) and forgets last (Crystal, 1982); also it is what 


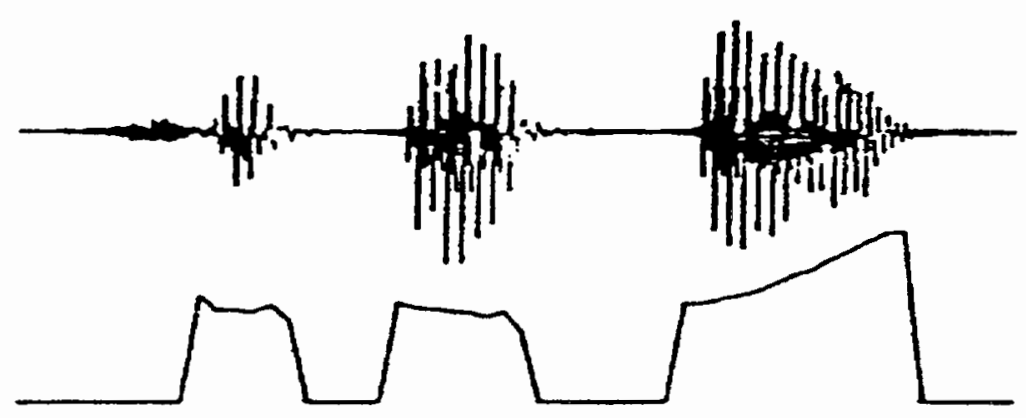

C'est papa?

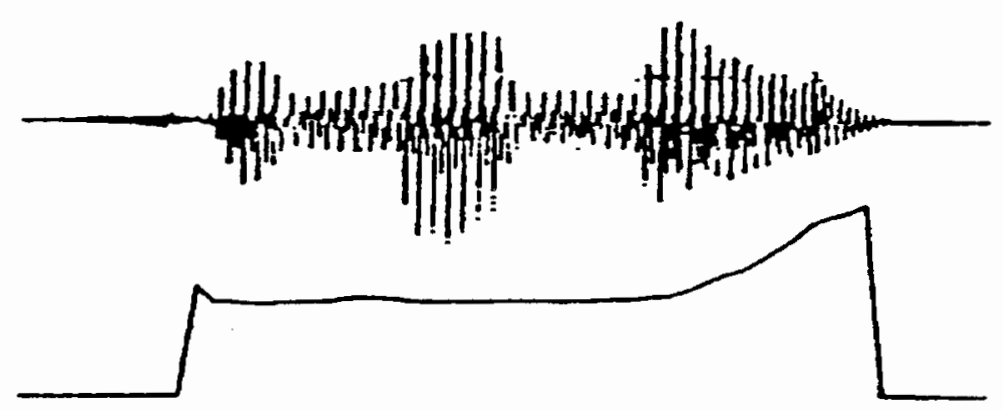

C'est maman?

Figure 1: Waveform (upper line) and fundamental frequency (lower line) for the utterances C'est papa? and C'est maman? (after Hirst 1983)

most often betrays the foreignness of a nearly perfect foreign language speaker (Coulmas, 1981).

The ear, we said, focuses selectively on different aspects of the sound stream. The role played by attention in this process, although not fully understood, seems to be very important (Robinson and Petersen, 1986). People generally hear prosodic contrasts that they are prepared by cultural experience to hear, and often "mishear", or do not perceive, contrasts that they are not prepared to hear. For this reason an English speaker, for example, may have great difficulty distinguishing between semantically or grammatically significant Xhosa clicks, Portuguese nasalizations, Chinese tones, and so on, while members of these cultures may have equal difficulty mastering important features of Eng- 
lish prosody. It seems that prosodic perceptions are thus not exactly invented by the ear but learned, like linguistic ones. Thus regarded, the filling in of acoustic gaps at the prosodic perceptual level may be an important interpretive activity not unlike the filling in of missing words, meanings, or syntactic features in our linguistic perceptions of speech.

Psychoacoustic experiments suggest that what the ear reacts to are not pitch levels as such, but pitch contrasts, i.e., changes in pitch direction (Hirst, 1983:94). Yet notions of contrastiveness are notoriously difficult to define with respect to prosody - which, being comprised almost entirely of graded phenomena, is somewhat more difficult to model than language, with its relatively distinct lexical and syntactic contrasts (Ross, 1985). Because prosodic contrasts are not inherent in single sounds/phonemes, but in longer segments, recognition of prosodic contrasts presupposes some type of normative, culturally learned knowledge of acoustic polarities, e.g., loud/quiet, high/low, etc. (Hille, 1961). To recognize prosodic contrast one must have some sense of the opposite pole.

An interesting notion suggested by Esser (1979) and Raith (1984) is that prosodic activities are interpretable in terms of two basically different types of contrasts: (1) discrete contrasts, such as falling/rising pitch, stressed/unstressed syllables, articulated/nonarticulated sequences (pauses), etc.; and (2) gradual contrasts, such as the relative height of a rise, speed of a fall, strength of a stress, length of a pause, etc. A problem of prosodic description, they claim, is that prosodic signals may be perceived in either of these two ways. It is possible that the two types of contrasts are also interpreted in different ways, with discrete contrasts yielding propositional interpretations (question/statement, semantic focus, etc.) and gradual contrasts yielding nonpropositional interpretations (confident/insecure, friendly/unfriendly, emotionally involved/uninvolved, etc.) (Arndt and Janney, 1987b).

Before moving on to consider some important cognitive-emotional aspects of prosody, we will summarize briefly. It is clear from the preceding discussion that there is no simple answer to the question of whether prosodic patterns are, in the narrowest sense, observational or introspective facts of speech. This is true not only of prosodic patterns, but of linguistic, paralinguistic, kinesic, and other patterns of speech activity as well. Ultimately, the facts of speech are only descriptions that are responsive to certain interests (Gebauer, 1980). With respect to the reality of prosody: yes, certain vocal phenomena that we categorize as "prosodic" can be measured and analyzed with acoustic devices. However, the acoustic data do not always correspond with our introspective notions about the nature of prosody and how it signals meaning in speech. On the other hand, the culturally experienced human ear seems to be a much more sophisticated and selective analyzer of native language acoustic events than the most advanced pitch extractor - one that is capable even of filling in mis- 
sing acoustic information, when necessary, to perceive prosodic effects when these may be only dimly suggested, or not even present in the acoustic record. Are prosodic categories ultimately observational or introspective? Paradoxically, the answer seems to be that they are a bit of each.

\section{Prosody, cognition and emotion}

"Feelings are the germ and starting point of cognition, thought the developed tree." W. James $(1890: 222)$

A question that linguists have long asked is how (or what) prosody contributes to the meaning of speech. The fact that no satisfying simple answer to this question has been offered up to now suggests the complexity of the issue (Hirst, 1983 : 93). What types of information do we rely on prosody to provide? Do prosodic activities convey universal symbolic meanings in their own right (Cruttenden, $1981: 77$ ), or do they only have a signalling value relative to the other verbal and nonverbal activities with which they occur (Gumperz, 1982 : 104)? In the absence of explicit semantic criteria, the discussion of prosodic meaning poses difficult theoretical and methodological problems (McGregor, $1982: 123$ ).

\subsection{Cognitive and emotive standpoints in prosodic research}

Despite the growing literature on prosodic univerals in recent years (Bolinger, 1964; Ladd, 1980; McGregor, 1982; Cruttenden, 1981, 1984; Holenstein, 1985), no one has succeeded yet in demonstrating convincingly that there are clear one-to-one correspondences between prosodic forms and their meanings in speech. A rising tone, as Crystal (1979 : 37$)$ says, "signals far more than a questioning meaning, and a grammatical question may be uttered using other tones than rising ones". Nevertheless, two dichotomous standpoints have long dominated the discussion of prosodic meaning in linguistics: one cognitively oriented, the other emotively oriented.

According to what we may call the cognitive standpoint, prosody has essentially propositional functions in speech. Stress, for example, signals lexical contrasts, e.g.,

'con tent $v s$. con 'tent

while intonation signals syntactic contrasts, e.g., 
That is Andy. (syntactic statement)

vs.

Is that Andy? (Syntactic question)

From the cognitive standpoint prosody is regarded as a vocal subsystem of language (see Section 4), and the meanings of prosodic features are regarded as grammatical meanings (Chomsky and Halle, 1968; Bresnan, 1972; Berman and Szamosi, 1972).

According to what we may call the emotive standpoint, on the other hand, prosody has pragmatic attitudinal functions in speech (Kingdon, 1958; Liberman, 1978; Brazil and Coulthard, 1980; Ladd, 1980). Tonal configurations, viewed as word-like semantic units, signal emotive information that enables partners to interpret each other's motives, feelings, and/or communicative intentions in the situation, e.g.,

\begin{tabular}{|c|c|}
\hline 'ready & (assertion of fact) \\
\hline 'READY & $\begin{array}{l}\text { vs. } \\
\text { (expression of excitement } \\
\text { or impatience) }\end{array}$ \\
\hline 'ready & $\begin{array}{c}v s . \\
\text { (request for confirmation) }\end{array}$ \\
\hline 'READY & $\begin{array}{l}\text { vs. } \\
\text { (expression of surprise } \\
\text { or disbelief) }\end{array}$ \\
\hline
\end{tabular}

From the emotive standpoint prosody is regarded as a quasi-independent mode of vocal expression, and the meanings of prosodic features are regarded as attitudinal meanings (Bolinger, 1982; Gumperz, 1982; Knowles, 1984).

In their most extreme forms both standpoints present problems that are difficult to solve without ignoring large areas of respected linguistic scholarship. Here we will not discuss the pros and cons of these, but simply say that the relationship between cognitive and emotional influences on prosody remains an important unresolved issue (Couper-Kuhlen, $1986: 182 \mathrm{ff}$.). In psychology, after years of controversy about the relative importance of these in human behaviour (Lazarus, 1982, 1984; Zajonc, 1980, 1984; Buch, 1984, 1986), there are signs of an integrative movement, and the interplay between cognitive and emotional processes has become an interesting new area of study (LeDoux and Hirst, $1986: 3$ ).

The findings suggest that cognition and emotion are no less closely related in prosody than they are in the rest of human behaviour. As Sapir (1927: 895) says, "if we are swayed by a particular thought or emotion, we may express ourselves with our hands or some other (means), and the voice takes part in the 
total play" (emphasis added). Yet, the prosodic contrasts by which different types of cognitive and emotional information are communicated are so nearly identical - even interchangeable - that it is often difficult to distinguish between their propositional and pragmatic functions on any level other than a purely analytical one (Brazil, 1972:2; McGregor, 1982:1). This being the case, it might be profitable for linguists to follow the psychologists' lead, and begin investigating how functions such as "information structuring" (Cutler, 1984 : 86 ) and emotional highlighting (Bolinger, $1972: 644$ ) are coordinated in prosody.

\title{
3.2 Cognitive, emotive and emotional prosodic communication
}

Buck's $(1984,1986)$ notion of spontaneous versus symbolic communication, and Stankiewicz's (1964) notion of emotional versus emotive communication provide a good theoretical foundation for discussing the interplay between cognitive and emotional processes in prosody. On the basis of a great number of clinical research findings on communicative deficits of brain-damaged patients, Buck (1986: 281 ff.): (1) spontaneous communication, or the relatively automatic, biologically structured, innate, unconscious, nonpropositional expression of internal motivational/emotional states; and (2) symbolic communication, which he describes as intentional, propositional, culturally structured, learned and conscious (Buck, 1983, 1984). The clinical evidence suggests that these two types of communication are relatively multimodal: that is, people communicate both spontaneously and symbolically in the verbal, prosodic, and kinesic modes, and brain injuries affecting one or the other type of communication tend to result in deficits across these modes (Buck, 1983).

With respect to the prosodic mode, Buck's description of spontaneous communication seems to fit many paralinguistic activities (at least those not consciously performed for strategic purposes), and certain types of extreme prosodic stress or articulatory force caused by surprise, excitement, anger, joy, or some other strong emotion, e.g.,

\author{
Look who's 'COMING \\ 'HELP me \\ We're 'WINNING \\ Get 'LOST
}

According to Buck (1986), we are dealing with spontaneous, nonpropositional, or emotional prosody in instances where prosodic variations in loudness, articulatory force, or intonation are exaggerated to such an extent that they no longer simply signal the salience of words in utterances (Gumperz, $1982: 109$ ) 
or provide information focus (Bolinger, $1972: 633$ ) but also seem unconsciously to signal something about the speaker's internal psychic state.

On the other hand, we are dealing with what Buck calls symbolic, propositional, or cognitive prosody in instances where prosodic signals are consciously used in conventional linguistically significant ways: that is, where contrasts (voiced/unvoiced, stressed/unstressed, falling/rising) are produced in rhythmic sequences that serve only as inputs to cognitive schemata for disambiguating utterances (Esser, 1979; Ladd, 1980; Raith, 1984), e.g.,

I want three of those (not five of them)

I want three of those (not of the others)

The answer is yes. (statement)

The answer is yes? (question)

She likes the toy shop (the shop)

She likes the toy shop (the toy)

The strength of Buck's notion is that it is supported, as we said, by considerable clinical neurological research (Arndt and Janney, 1986; Arndt, Janney and Schaffranek, 1986), and it seems to apply to a wide variety of linguistic, prosodic, and kinesic phenomena. With such concepts it is possible to approach speech activities in different modes from a unified point of view and explain, for example, functional interrelationships between these in the two communicative domains (Arndt and Janney, 1987b).

A problem with Buck's idea, on the other hand, is that it does not seem to acknowledge the very large, and in our opinion important, range of nonpropositional communicative activities that do not fit easily into categories like "biological/cultural", "innate/learned", and "unintentional/intentional": namely, activities by which people consciously communicate real or projected emotional information for strategic purposes in order to influence others' perceptions and interpretations of them in different situations.

The literature on prosody contains many references to emotional prosody: "Emotion, it appears, has a language of its own" (Couper-Kuhlen, 1986 : 173), "Wer wütend die Stimme hebt, tut dies weder auf Deutsch noch auf Englisch, sondern eben nur wütend" (Lieb, $1980: 34$ ), and so on. It also contains references to this second type of nonpropositional prosody, which, following Stankiewicz (1964), we will call emotive prosody: 
... the melodic expression of attitudes may be more or less perfectly integrated into the linguistic code. (Fónagy and Bérard, 1972 : 173).

... the phrase "thank you" may be said with one tune which makes it sound genuinely grateful, and with a different tune which makes it sound rather casual (O'Connor and Arnold, 2/1973:2).

The vocal choices involved in making thank you sound genuinely sincere or only conventionally polite are at least as conscious, intentional, and culturally structured as the verbal lexical and syntactic choices that they accompany (modulate, modify, clarify, etc.). They are not, however, propositional choices; and as Tetens suggests, they are not necessarily purely emotional choices, as they are derived from cognitively mediated, reflected feelings - from the speaker's awareness, that is, of this or her emotional state and how this may be perceived or interpreted by the partner (Tetens, $1913: 54$ ).

Stankiewicz (1964) distinguishes between two types or planes of nonpropositional communication: (1) an emotional plane, which is characterized by articulated or unarticulated sound gestures of a purely instinctive, symptomatic, unplanned nature, i.e., Buck's (1986) spontaneous communication, or what Faure (1970) calls "the autistic expression of affect"; and (2) an emotive plane, which is characterized by the learned, systematic, conscious use of nonpropositional sound gestures - those referred to above or others - to influence other people's behaviour (Couper-Kuhlen, 1986:173 ff.). Faure (1970) claims that the latter displays of affect are culturally rule-governed and are subject to will, reflection, and various motivational influences.

On the basis of these notions, we may distinguish between three broad dimensions of prosodic communication: cognitive, emotive, and emotional (see Figure 2). Cognitive and emotive prosodic communication are complex, intentional, culturally learned activities. The voice varies constantly in response to the semiotic and interactional demands of the situation, shaping, organizing, and helping interpret the flow of propositional linguistic information on the one hand, while signalling affective information and helping the partners regulate interpersonal relationships on the other. Both propositional and nonpropositional information are necessary to successful interaction. The former enables the partners to negotiate their respective understandings of what is literally going on in the conversation, and the latter enables them to infer its emotional significance and predict what may happen next. While emotional prosodic communication is largely reflexive, and therefore not intentionally communicative but rather only incidentally so, it is nevertheless an important aspect of speech, for it enables speakers to release emotional tension and main- 


\begin{tabular}{|c|c|c|c|}
\hline & COGNITIVE & EMOTIVE & EMOTIONAL \\
\hline ACTIVITY & $\begin{array}{l}\text { learned: } \\
\text { the conscious use } \\
\text { of prosodic cues } \\
\text { to signal proposi- } \\
\text { tional information }\end{array}$ & $\begin{array}{l}\text { learned: } \\
\text { the conscious use } \\
\text { of prosodic cues } \\
\text { to signal affec- } \\
\text { tive information }\end{array}$ & $\begin{array}{l}\text { learned: } \\
\text { the spontaneous vocal/ } \\
\text { prosodic externaliza- } \\
\text { tion of internal af- } \\
\text { fective states }\end{array}$ \\
\hline FRAME & $\begin{array}{l}\text { sociosemiotic: } \\
\text { the need to follow } \\
\text { vocal semiotic con- } \\
\text { ventions in order } \\
\text { to be understood }\end{array}$ & $\begin{array}{l}\text { interactional: } \\
\text { the need to adapt } \\
\text { behaviourally to } \\
\text { others in order } \\
\text { to avoid con- } \\
\text { flicts }\end{array}$ & $\begin{array}{l}\text { psychobiological: } \\
\text { the need to adapt } \\
\text { physiologically to } \\
\text { powerful internal } \\
\text { psychic stimuli }\end{array}$ \\
\hline FOCUS & $\begin{array}{l}\text { message: } \\
\text { the propositional } \\
\text { form and salience } \\
\text { of the verbal mes- } \\
\text { sage in the situa- } \\
\text { tion }\end{array}$ & $\begin{array}{l}\text { partner: } \\
\text { the partner's in- } \\
\text { terpersonal at- } \\
\text { titudes, percep- } \\
\text { tions, and inter- } \\
\text { pretations in the } \\
\text { situation }\end{array}$ & $\begin{array}{l}\text { self: } \\
\text { the speaker's intemal } \\
\text { affective states in } \\
\text { the situation }\end{array}$ \\
\hline FUNCTION & $\begin{array}{l}\text { logistic: } \\
\text { organizes and helps } \\
\text { interpret the flow } \\
\text { of propositional } \\
\text { linguistic infor- } \\
\text { mation }\end{array}$ & $\begin{array}{l}\text { strategic: } \\
\text { signals affective } \\
\text { information and } \\
\text { influences the } \\
\text { partner's behav- } \\
\text { ior toward the } \\
\text { speaker }\end{array}$ & $\begin{array}{l}\text { cathartic: } \\
\text { releases emotional } \\
\text { tension and helps the } \\
\text { speaker maintain } \\
\text { psychic balance }\end{array}$ \\
\hline
\end{tabular}

Figure 2: Cognitive, emotive, and emotional dimensions of prosody

tain psychic balance, and it gives partners additional information about each other's feelings.

Before turning to discuss some relationships between prosody, language, paralanguage, and kinesics, we summarize the main points of this section. In the light of modern neuropsychological findings about cognition and emotion, the argument in linguistics about whether prosody is a cognitive or emotional phenomenon seems somewhat outdated (Plutchik and Kellerman, 1980; Buck, 1983, 1984, 1986; Frijda, 1986; LeDoux and Hirst, 1986). If there is no simple answer to this question, it is perhaps because the interplay between cognitive and emotional influences in prosody is too complex to be accounted for with our present practice of focusing on those instances where prosodic phe- 
nomena confirm our assumptions about their functions, and ignoring the instances where they do not. Prosody is a multifunctional communicative mode that enables people to vocally structure linguistic information (its cognitive function) while consciously signalling attitudinal information (its emotive function), and spontaneously releasing internal psychic pressure (its emotional function). Yet, theoretical and methodological necessities force us to reduce this complexity to relatively simple, dichotomous, conceptual categories such as those discussed throughout the paper. This practice can hardly be criticized, as it is doubtful whether linguistics or any other science could exist without making reductions (Moore and Carling, $1982: 5$ ). Still, it is worth remembering that the human voice communicates cognitive, emotive, and emotional information simultaneously during speech, with no clear division of labour, making prosodic contrasts (Esser, 1979; Raith, 1984) propositionally, pragmatically, and personally relevant to the partners at all times.

\section{Prosody, paralanguage, language, and kinesics}

"Whatever else intonation may be, it cannot be divorced from ... our bodies."

D. Bolinger (1982: 525)

In this section we will address a question that may some day provide the key to a great many unresolved issues in prosodic theory (Gibbon and Richter, 1984: 2 and Couper-Kuhlen, $1986: 184$ ): the question of whether prosody is best regarded as a subsystem of language, or as an independent communicative system in its own right. As we suggested earlier, scholars are deeply divided on this point (see Section 3.1). According to some, prosodic contrasts are just as grammatical as are those, such as tense, number and mood, expounded by other means (Halliday, $1967: 10$ ), and for this reason, they may be integrated into the general framework of grammar and treated as aspects of language (Liberman, 1975; Liberman and Prince, 1977; Selkirk, 1978; Bing, 1979; Halle and Vergnaud, 1979; Safir, 1979; Chomsky, 1981; Ronat, 1984). According to other linguists, prosody is an autonomous semiotic system which plays a rather different role than the verbal system (Knowles, $1984: 277$ ); and prosodic phenomena may be separated from grammar and treated as independent vocal gestures that occur in speech with, but not determined by, propositional linguistic activities on the one hand, and with, but not determined by, nonpropositional paralinguistic and kinesic activities on the other (Sapir, 1927; Bloomfield, 1933; Pike, 1954; Hultzén, 1956; Bolinger, 1972; Poyatos, 1981; Cutler, 1984; Fuchs, 1984).

In the debate over the years about the status of prosody in linguistics, terms such as "vocal/kinesic", "linguistic/nonlinguistic" and "verbal/nonverbal" have 
been used with a systematic ambiguity that has enabled scholars generally to define prosody and study its relationships to other speech phenomena rather as they please (see Figure 3).

\section{SPEECH PHENOMENA}

\begin{tabular}{ll}
\hline $\begin{array}{l}\text { VOCAL } \\
\text { language + prosody + paralanguage }\end{array}$ & $\begin{array}{l}\text { KINESIC } \\
\text { kinesics }\end{array}$ \\
\hline $\begin{array}{l}\text { LINGUISTIC } \\
\text { language + prosody }\end{array}$ & $\begin{array}{l}\text { NONLINGUISTIC } \\
\text { paralanguage + kinesics }\end{array}$ \\
\hline $\begin{array}{l}\text { VERBAL } \\
\text { language }\end{array}$ & $\begin{array}{l}\text { NONVERBAL } \\
\text { prosody + paralanguage + kinesics }\end{array}$ \\
\hline
\end{tabular}

Figure 3: The position of prosody in the terminological hierarchy of speech phenomena

Depending on their orientation within a particular research tradition, scholars tend to align prosody either more closely with language or with kinesics. An alignment of prosody with language and paralanguage as a vocal phenomenon, and the exclusion of kinesics from consideration, for example, is typical of electronic speech processing research. For purposes of investigating prosody as pure sound, scholars assume that it is physiologically motivated, and measurable in terms of signals of particular amplitudes and durations with given fundamental frequencies, harmonics, and other linear acoustic characteristics (Markel and Gray, 1976; Klein, 1982; Krause, 1984; Richter, 1984; Hirst and di Cristo, 1984). An alignment of prosody with language as a linguistic phenomenon, on the other hand, and an exclusion of paralanguage and kinesics, is typical of various grammatical approaches to prosody. For purposes of investigating prosody as a linguistic phenomenon, grammatically oriented scholars assume that it is mainly cognitively motivated, culturally acquired, symbolic, propositional, and language-dependent (Chomsky and Halle, 1968; Hooper, 1976; Selkirk, 1980; Dogil, 1984). An implicit alignment of prosody with paralanguage and kinesics as a nonverbal phenomenon, finally, is typical of various gestural approaches to prosody. For purposes of investigating prosody as a nonverbal phenomenon, these scholars tend to assume that it is primarily emotionally motivated, biologically acquired (but culturally modified), nonpropositional, and more or less independent of language (Birdwhistel1, 1970; Kendon, Harris and Key, 1975; Kendon, 1981; Key, 1975, 1977, 1980, 1982; Poyatos, 1983a, 1983b).

One of the intriguing questions raised by these different approaches to prosody is whether vocal variations in loudness, pitch, duration, and so on are 
ultimately best considered to be psychosemiotic phenomena or psychobiological ones. Are they finally products of the "mind" or the "body" (Birdwhistell, $1970: 66 \mathrm{ff}$.; Sarles, $1977: 227 \mathrm{ff}$.)? Are they, broadly speaking, symbolic or symptomatic (Ekman and Friesen, 1967; Seaford, 1981)? Without wishing to revive the old mind-body debate here (Tibbetts, 1973), we will only suggest that prosody is an example par excellence of a speech phenomenon that resists our attempts to draw clear conceptual distinctions between mental and physical processes.

In an interesting study of stuttering, Krause (1982) points out that one of the preconditions for speech seems to be the capacity to synchronize complex series of body processes such as breathing, producing sounds, making kinesic movements, and so on. The capacity to coordinate body movements seems to be a physiological prerequisite for normal speech (Bullowa, 1975). "Disturbances of this bodily basis of spoken language lead to disturbances of speech production proper, whereby the cognitive planning of the message, at least the semantic part, is not affected. This is what the stuttering of an adult essentially consists of" (Krause, 1982: 92). The importance of the synchronization of complex body processes in speech suggests, among other things, that prosody, language, paralanguage, and kinesics must be highly interrelated and interdependent at some level of neurobiological organization (Changeux, 1984; Maturana, 1985).

Perceptually, the interrelatedness of the various sensory modalities, or "intersensory integration", as Davenport (1977: 74) calls it, is known to play a great role in infant language learning. This interrelatedness - variously termed intermodal transfer, cross-modal transfer, intermodal integration, intermodal generalization, cross-modal perception, etc. - seems in some way to complement, at the sensory level, the production of complexly interrelated linguistic, prosodic, paralinguistic and kinesic activities at the motor level of speech. Evidence supporting a relationship between cross-modal perception and cross-modal production of speech signals comes from the ontogenetic improvement of the former accompanying the development of verbal language in children (Lock, 1978, 1980). However, neurological findings show that "it cannot be argued that the ability to form cross-modal associations depends on already having speech; rather we must say that the ability to acquire speech has as a prerequisite the ability to form cross-modal associations" (Geschwind, 1965: 175).

With respect to the question of whether prosody is best regarded as a subsystem of language or an independent communicative system in its own right, the findings again seem paradoxical. On the one hand we know that in the English language, relationships between grammar and prosody, as Bolinger, (1958) says, tend to be rather casual. On the other hand, in tone languages such as Vietnamese and Chinese, intonational contrasts play a much more important 
role in determining lexical meanings of words and are much more firmly embedded in grammar than is English prosody (Halliday, 1967:10).

\section{IMPLICATIONS}

"Let us repeat that there is no autonomy without integration and no integration without autonomy."

R. Jakobson and L. Waugh (1979: 234)

Ultimately, the paradoxes of prosodic research invite us to consider how our theories relate to the real world, and ask what we have discovered up to now about the nature of prosody and its contribution to speech. The impression perhaps created by our juxtaposition of opposing views in this paper is that there are no concrete answers to these questions. Prosody might be too complex, as an acoustic phenomenon, to be fully measured with existing electronic equipment (Krause, 1984), and we have not yet developed sufficiently differentiated notational systems for describing what we hear (Hirst, 1983). It is reasonably certain, at any rate, that important features of prosodic communication - especially the relationships between prosodic and paralinguistic vocalizations - lie beyond the scope of our present approaches.

The standpoints discussed in the preceding sections yield a curious list of contradictions. Putting them together, we could describe prosody as a vocal observational-introspective fact of speech originating in the mind-body that is biologically-culturally acquired, cognitively-emotionally motivated, and propositionally-nonpropositionally meaningful in a symbolic-gestural fashion. The reader might come to the conclusion that these dichotomies per se are useless, or even detrimental, to the study of prosody.

Yet, we finally have little choice but to proceed by means of such distinctions if we wish to reduce complex prosodic phenomena (however we perceive and define them) to objects of analysis and study these systematically from a scientific point of view. Conceptual frameworks, as Karl Popper (1959) says, are like nets: only if we throw them can we capture aspects of reality. Reductive approaches must thus of necessity be accepted as our only means of imposing system on prosodic reality and, in so doing, making prosody describable and explainable

For scholars who study speech as multimodal communication, prosodic research raises interesting questions for future study. The conflicting results of acoustic analysis and observer impressions of prosodic events are a case in point (see Section 2.3). The fact that people apparently perceive sentence accents, stressed and unstressed syllables, and smoothly rising and falling pitch contours where none are acoustically measurable is paradoxical (Klein, 1982; Hirst, 1983; Krause, 1983). Proponents of empirical and introspective meth- 
ods often regard this as proof that each other's approaches to analyzing prosody are defective. However, from a multimodal point of view, the thought lies near that prosodic perceptions may be influenced to some extent by linguistic and kinesic perceptions, and that these, in turn, are influenced by cultural and situational expectations (Andt and Janney, 1987b : $57 \mathrm{ff}$.). It thus would be interesting to investigate the extent to which prosodic perceptual expectations and impressions of nonexistent prosodic features are related to similar phenomena in the linguistic and kinesic domains.

The notion of discrete versus gradual contrasts is also interesting from a multimodal point of view (see Section 2.3) (Esser, 1979; Raith, 1984). On closer consideration, the distinction between discrete (fall/rise) and gradual (height or gradient of fall/rise) vocal contrasts seems somewhat reminiscent of the distinction between formal and stylistic verbal contrasts; and both seem to be related to the more general distinction in all human behaviour between what and how activities are performed. As such, it is essentially a perceptual distinction, not necessarily a behavioural one, and could apply to communicative activities in all modes. A task for future multimodal research might be to investigate to what extent perceptions of discrete and gradual contrasts are relevant to the interpretation of complex multimodal verbal, prosodic and kinesic speech events.

Another notion of interest is the distinction between cognitive, emotive and emotional planes of communication (see Section 3.2) (Stankiewics, 1964; Couper-Kuhlen, 1986; Buck, 1984, 1986). These are dimensions not only of prosodic communication, but of linguistic and kinesic communication as well, and we can construct theoretical models that explain how these three types of information are signalled in the different modes and are cross-modally modified in speech. (Arndt and Janney, 1987b). More work, however, must be devoted to investigating how these are related to, and guided by, neurological processes.

Finally, distinguishing between psycho-semiotic, socio-psychological, and psycho-biological influences on prosody remains an interesting problem for future research. Presently we know too little about what Krause (1982: 92) calls "the bodily basis of speech" to formulate the questions properly perhaps, but research may someday yield information about how these influences are synchronized. The next step in multimodal research will be the search for the "central organizer": the neurobiological basis of coordinated verbal, vocal, and kinesic speech activities (Cicone, Wapner, Foldi, Zurif, and Gardner, 1979). When this is discovered, perhaps prosody will stop seeming so paradoxical. 


\section{References}

ARNDT, H. 1981. Linguistische Modelle und Fremdsprachendidaktik: das Transpositionsproblem. Die Neueren Sprachen, Vol. 80, No. 5, 372 - 377.

ARNDT, H \& R.W. Janney. 1981. Intuitive linguistic knowledge as a problem of nonautonomous linguistic research: The verbal coordination of group role identities. Forum Linguisticum, Vol. 7, No. 6, 95 - 116.

ARNDT, H. \& R.W. Janney. 1985a. Improving emotive communication: Verbal, prosodic and kinesic conflict-avoidance techniques. Per Linguam, Vol. 1, No $1,21-33$.

ARNDT, H. \& R.W. Janney. 1985b. Politeness revisited: Cross-modal supportive strategies. International review of applied linguistics, Vol. 23, 281 - 300.

ARNDT, H. \& R.W. Janney. 1986. Neurological parameters of human multimodal communication. Sociologia Internationalis, Vol. 24, 143 - 169.

ARNDT, H. \& R.W. Janney. 1987a. The biological and cultural evolution of human communication. In: Lörscher, Wolfgang and Rainer Schulze eds. Perspectives on language performance. Tübingen: Narr, $19-45$.

ARNDT, H. \& R.W. Janney. 1987b. InterGrammar. Toward an integrative model of verbal, prosodic and kinesic choices in speech. Berlin, New York and Amsterdam: Mouton de Gruyter.

ARNDT, H. \& R.W. Janney \& H.W. Pesch. 1984. Trimodale Interaktion: Grundlagen zur integrierten Interpretation von Sprache, Prosodie und Gestik. Die Neueren Sprachen, Vol. 83, No. 5, 489 - 512.

ARNDT, H. \& R.W. Janney \& G.Schaffranek. 1986. A neurological view of prosody and its importance in human communication. Die Neueren Sprachen, Vol. 85, No. 5-6, 581 - 609 .

ARNDT, H. \& H.W. Pesch. 1983. Soziokinetische Aspekte sprachlicher Interaktion: Zur Rolle von Illustrationen in Lehrbüchem. Die Neueren Sprachen, Vol. 82 , No. $1,27-45$.

ARNDT, H. \& H.W. Pesch. 1984. Nonverbal communication and visual teaching aids: A perceptual approach. The modern language journal, Vol. 68, 28 - 36.

ARNDT, H. \& W.E. Stewart. 1982. Linguistic universals: Implications of a neurological reappraisal of Jakobson's phonological hierarchy. South African journal of psycholggy, Vol. 12, No. 4, 118 - 129. 
ARNDT, H. \& W.E. Stewart. 1983. On the cerebral representation of affective language components with special reference to intonation. Nagoya Gakuin University Round Table, No. 8, 17 - 25.

BERMAN, A.\& M.Szamosi. 1972. Observations on sentential stress. Language, Vol. $48,304-325$.

BING, J.M. 1979. Aspects of English prosody. Ph.D. dissertaton, University of Massachusetts, Amherst.

BIRDWHISTELL, R.L. 1970. Kinesics and context. Philadelphia: University of Pennsylvania Press.

BLOOMFIELD, L. 1933. Language. New York: Holt.

BOLINGER, D.L. 1958. A theory of pitch accent in English. Word, Vol. 14, 109 - 149.

BOLINGER, D.L. 1964. Intonation as a universal. In: Lunt, H.G. ed. Proceedings of the ninth international congress of linguistics, Cambridge, Mass., 1962. The Hague: Mouton, 833 - 848.

BOLINGER, D.L. ed. 1972. Intonation. Harmondsworth, England: Penguin.

BOLINGER, D.L. 1975. Aspects of language. New York: Harcourt.

BOLINGER, D.L. 1982. Intonation and its parts. Language, Vol. 58, 505 - 533.

BOYSSON-BARDIES, B. DE. 1982. Les bébés babillent-ils dans leur langue maternelle? La Recherche, Vol. 129, 102 - 104.

BRAZIL, D. 1975. Discourse intonation. Birmingham: University of Birmingham Press.

BRAZIL, D. \& M. Coulthard. 1980. Discourse intonation and language teaching. London: Longman.

BRESNAN, J.W. 1971. Sentence stress and syntactic transformations. Language, Vol. $47,257-281$.

BRESNAN, J.W. 1972. Stress and syntax: A reply. Language, Vol. 48, 326 - 342.

BUCK, R. 1983. Emotional development and emotional education. In: Plutchik, R. and H. Kellerman eds. Emotions in early development. New York: Academic Press, 259 - 292.

BUCK, R. The communication of emotion. New York and London: Guildford Press. 
BUCK, R. 1986. The psychology of emotion. In: LeDoux, Joseph E. and William Hirst eds. Mind and brain. Dialogues in cognitive neuroscience. Cambridge, UK: Cambridge University Press, 275 - 300.

BULLOWA, M. 1975. When infant and adult communicate how do they synchronize their behaviours? In: Kendon, A., R.M. Harris and M.R. Key eds. Organization of behaviour inface-to-face interaction. The Hague: Mouton.

BUNGE, M.A. 1973. Method, model and matter. Dordrecht: Reidel.

CHANGEUX, J.P. 1984. Der neuronale Mensch. Reinbek: Rowohlt.

CHOMSKY, N. \& M. Halle. 1968. The sound pattern of English. New York: Harper and Row.

CHOMSKY, N. 1981. On the representation of form and function. The linguistic review, No. 1, 3 - 40 .

CICONE, M., W. Wapner, N. Foldi, E. Zurif \& H. Gardner. 1979. The relation between gesture and language in aphasic communication. Brain and language, Vol. 8, 324 - 349 .

COULMAS, F. 1981. Spies and native speakers. In: Coulmas, Florian ed. Conversational routine. Explorations in standardized communication situations and prepatterned speech. The Hague: Mouton, 355 - 367.

COUPER-KUHLEN, E. 1986. An introduction to English prosody. Tübingen: Niemeyer.

CRUTTENDEN, A.: 1981. Falls and rises: meanings and universals. Journal of linguistics, Vol. 17, 77 - 91 .

CRUTTENDEN, A. 1984. The relevance of intonational misfits. In: Gibbon, D. and H. Richter eds. Intonation, accent and rhythm. Berlin and New York: de Gruyter, 67 - 76.

CRYSTAL, D. 1975. The English tone of voice. London: Edward Amold.

CRYSTAL, D. 1979. Prosodic development. In: Fletcher, P. and M. Garman eds. Language acquisition. Cambridge University Press, 33 - 48.

CRYSTAL, D. 1982. Profiling prosodic disability. BAAL Seminar on intonation and discourse. Birmington: University of Aston.

CUTLER, A. 1982. Speech errors: a classified bibliography. Bloomington, In: Indiana University Linguistic Club. 
CUTLER, A. 1984. Stress and accent in language production and understanding. In: Gibbon, D. and H. Richter eds. Intonation, accent and rhythm. Berlin and New York: de Gruyter, 77 - 90.

DAVENPORT, R.K. 1977. Cross-modal perception: A basis for language. In: Rumbauch, D.M. ed. Language learning by a chimpanzee. The Lana project. New York: Academic Press, 73 - 83.

DOGIL, G. 1984. Grammatical prerequisites to the analysis of speech style: Fast/casual speech. In: Giboon, D. and H. Richter eds. Intonation, accent and rhythm. Studies in discourse phonology. Berlin and New York: de Gruyter, 91 - 119.

EKMAN, P. \& W.V. Friesen. 1967. Head and body cues in the judgment of emotion: A reformulation. Perceptual and motor skills, Vol. 24, 711 - 724.

ESSER, J. 1979. Englische Prosodie: Eine Einführung. Tübingen: Narr.

FAURE, G. 1970. Contribution à l'étude du statut phonologique des structures prosodématiques. In: Léon, P., G. Faure and A. Rigault eds. Prosodic feature analysis. Analyse des faits prosodiques. Ottawa: Didier, 93 - 108.

FóNAGY, I. \& E. Bérard. 1972. Il est huit heures: Contribution à l'analyse sémantique de la vive voix. Phonetica, Vol. 26, 157 - 192.

FRIJDA, N.H. 1986. The emotions. Cambridge, UK: Cambridge University Press.

FUCHS, A. 1984. Deaccenting and default accent. In: Gibbon, D. and H. Richter eds. Intonation, accent and rhythm. Berlin and New York: de Gruyter, 135 165.

GEBAUER, G. 1980. Warum das Sprechen von der Grammatik abweicht. Überlegungen zu einer Handlungstheorie des Sprechens. In: Lenk, H. ed. Handlungstheorien - interdisziplinär, Vol. 1, München: Fink, $403-437$.

GESCHWIND, N. 1965. Disconnection syndromes in animals and man. Brain, Vol. $88,237-294,585-644$.

GIBBON, D. Intonation as an adaptive process. In: Gibbon, D. and H. Richter eds. Intonation, accent and rhythm. Studies in discourse phonology. Berlin and New York: de Gruyter, $165-192$.

GIBBON, D. \& Helmut Richter eds. 1984. Intonation, accent and rhythm. Studies in discourse phonology. Berlin and New York: de Gruyter.

GOLDSMITH, J. 1982. Review of D.R. Ladd's The structure of intonational meaning. language, Vol. 58, No. 2, 422 - 424. 
GUMPERZ, J.J. 1982. Discourse strategies. Cambridge: Cambridge University Press.

HALLE, M. \& J.R. Vergnaud. 1979. Metrical structure in phonology: A fragment. Unpublished paper, Massachusetts Institute of Technology.

HALLIDAY, M.A.K. 1967. Intonation and grammar in British English. The Hague: Mouton.

HILLE, A. 1961. Suprasegmentals, prosodies, prosodemes. Language, Vol. 37.

HIRST, D.J. 1983. Interpreting intonation: a modular approach. Journal of semantics, Vol. 2, No. 2, 171 - 181.

HIRST, D. \& A. di Cristo. 1984. French intonation: A parametric approach. Die Neueren Sprachen, Vol. 83, 5, 554 - 569.

HOLENSTEIN, E. 1985. Sprachliche Universalien. Eine Untersuchung zur Natur des menschlichen Geistes. Bochum: Brockmeyer.

HOOPER, J. 1976. An introduction to natural generative phonology. New York: Academic Press.

HULTZéN, L.S. 1956. The poet burns again. American Speech, Vol. 31, 195 - 201.

JAKOBSON, R. \& L. Wauch. 1979. The sound shape of language. Brighton, UK: Harvester.

JAMES, W. 1980. The principles of psychology. Vol. 1. New York: Holt.

JANNEY, R.W. 1981. A metascientific view of the transformational-generative theoretical model. Die Neueren Sprachen, Vol. 80, No. 5, 422 - 435.

KENDON, A. ed. 1981. Nonverbal communication, interaction, and gesture. The Hauge: Mouton.

KENDON, A., R.M. Harris \& M.R. Key eds. 1975. Organization of behavior in faceto-face interaction. The Hague: Mouton.

KEY, M.R. 1975. Paralanguage and kinesics. Metuchen, NJ: Scarecrow.

KEY, M.R. 1977. Nonverbal communication. Metuchen, NJ: Scarecrow.

KEY, M.R. (ed.). 1980. The relationship of verbal and nonverbal communication. The Hague: Mouton.

KEY, M.R. 1982. Nonverbal communication today. Berlin and New York: Mouton. 
KINGDON, R. 1958. The groundwork of English intonation. London: Longman.

KLEIN, W. 1980. Der Stand der Forschung zur deutschen Satzintonation. Linguistische Berichte, Vol. 68, 3 - 33.

KLEIN, W. 1982. Einige Bemerkungen zur Frageintonation. Deutsche Sprache, Vol. $4,289-310$.

KNOWLES, G. 1984. Variable strategies in intonation. In: Gibbon, D. and H. Richter eds. Intonation, accent and rhythm. Berlin and New York: de Gruyter, 227 - 242.

KRAUSE, M. 1984. Recent developments in speech signal pitch extraction. In: Gibbon, D. and H. Richter eds. Intonation, accent and rhythm. Berlin and New York: de Gruyter, 243 - 252.

LADD, R.D. 1980. Intonational meaning. Bloomington: Indiana University Press.

LAZARUS, R.S. 1982. Thoughts on the relations between emotion and cognition. American psychologist, Vol. 37, 1019 - 1024.

LAZARUS, R.S. 1984. On the primacy of cognition. American psychologist, Vol. 39, $124-129$.

LEDOUX, J.E. \& William Hirst eds. 1986. Mind and brain. Dialogues in cognitive neuroscience. Cambridge: Cambridge University Press.

LIBERMAN, M. 1978. The intonational system of English. Bloomington: Indiana University Linguistic Club.

LIBERMAN, M. \& A. Prince. 1977. On stress and linguistic rhythm. Linguistic inquiry, Vol. 8, 249 - 336.

LIEB, H. H. 1980. Intonation als Mittel verbaler Kommunikation. Linguistische Berichte, Vol. 68, 34 - 48 .

LOCK, A. (ed.). 1978. Action, gesture, and symbol. The emergence of language. London: Academic Press.

LOCK, A. 1980. The guided reinvention of language. London: Academic Press.

MALINOWSKI, B. 1920. Classificatory particles in the language of Kiriwina. Bulletin of the school of oriental studies, Vol. 7, 33-78.

MARKEL, J.D. \& A.H. Gray. 1976. Linear prediction of speech. New York: Springer. 
MATURANA, H.R. 1985. Die Organisation und Verkörperung von Wirklichkeit. Ausgewählte Arbeiten zur biologischen Epistemologie. Braunschweig und Wiesbaden: Vieweg.

McGREGOR, G. 1982. Intonation and meaning in conversation. Language and communication, No. 2, 123 - 131 .

MOORE, T. \& C. Carling. 1982. Understanding language. London: Macmillan.

O'CONNOR, J.D. \& G.F. Amold. 1973. Intonation of colloquial English. London: Longman.

PIKE, K.L. 1954. Language in relation to a unified theory of the structure of human behavior. Preliminary edition. Glendale, CA: Summer Institute of Linguistics.

PLUTCHIK, R. \& H. Kellerman eds. 1980. Emotion. Theory, research, and experience. Vol. 1. New York and London: Academic Press.

POPPER, K.R. 1959. The logic of scientific discovery. New York: Basic Books.

POYATOS, F. 1981. Gesture inventories: Fieldwork methodology and problems. In: Kendon, A. ed. Nonverbal communication, interaction, and gesture. The Hague: Mouton, 371 - 399.

POYATOS, F. 1983a. Language and nonverbal systems in the structure of face-to-face interaction. Language and communication, 3, 129 - 140.

POYATOS, F. 1983b. New perspectives in nonverbal communication. Oxford: Pergamon.

RAITH, J. 1984. Die Funktion und Relevanz prosodischer Systeme im Interaktionsprozeß. Die Neueren Sprachen. Vol. 83, No. 5, 513 - 544.

ROBINSON, D.L. \& S.E. Petersen. 1986. The neurobiology of attention. In: LeDoux, J.E. and W. Hirst eds. Mind and brain. Dialogues in cognitive neuroscience. Cambridge: Cambridge University Press, 142 - 171.

RONAT, M. 1984. Logical form and prosodic islands. In: Gibbon, D. and H. Richter eds. Intonation, accent and rhythm. Studies in discourse phonology. Berlin and New York: de Gruyter, 311 - 326.

ROSS, E.D. 1985. Modulation of affective and nonverbal communication by the right hemisphere. In: Mesulam, M.M. ed. Principles of behavioral neurology. Philadelphia: Davis, 239 - 257. 
SAFIR, K. (ed.). 1979. Papers on syllable structure, metrical structure and harmony processes. Cambridge. MA: MIT Working Papers in Linguistics.

SAPIR,E. 1927. The unconscious patterning of behavior in society. In: Dummer, E.S. ed. The unconscious: A symposium. New York: Knopf, 114 - 142.

SARLES, H. 1977. After metaphysics. Toward a grammar of interaction and discourse. Lisse: De Ridder.

SAUSSURE, F. DE. 1916. Cours de linguistique générale. Paris: Payot.

SEAFORD, H.W.F.R. 1981. Maximizing replicability in describing facial behavior. In: Kendon, A. ed. Nonverbal communication, interaction, and gesture. The Hague: Mouton, 165 - 195.

SELKIRK, E. 1978. On prosodic structure and its relation on syntactic structure. Unpublished paper, Indiana University Linguistic Club.

SELKIRK, E. 1980. The role of prosodic categories in English word stress. Linguistic inquiry, Vol. 11, $563-605$.

STANKIEWICZ, E. 1964. Problems of emotive language. In: Sebeok, Th. A. et al. eds. Approaches to language. The Hague: Mouton, $239-276$.

TETENS, J.N. 1877. Philosophische Versuche über die menschliche Natur und ihre Entwicklung. 2 Vols. Leipzig: Weidmann.

TETENS, J.N. 1913. Philosophische Versuche über die menschliche Natur und ihre Entwicklung. Vol. 1. Über die allgemeine spekulativische Philosophie. Berlin: Von Reuther and Reichard.

TIBBETS, P. 1973. The mind-body problem: Empirical or conceptual issues? Psychological record, Vol. 23, 111 - 120.

TRAGER, G.L. 1958. Paralanguage: A first approximation. Studies in linguistics. Vol. 13, 1 - 12 .

VENNEMANN, T. 1986. Neuere Entwicklungen in der Phonologie. Berlin: Mouton de Gruyter.

WITTGENSTEIN, L. 1953. Philosophical investigations. New York: Macmillan.

ZAJONC, R.B. 1980. Feeling and thinking: Preferences need no inferences. American psychologist, Vol. 35, 151 - 175.

ZAJONC, R.B. 1984. On the primacy of affect. American psychologist, Vol. 39, 117 $-123$. 